\title{
TO BE A PRINCE IN THE FOURTH/TENTH-CENTURY ABBASID COURT
}

\author{
Nadia Maria El Cheikh
}

Court studies are almost nonexistent for early Islamic history, including the Abbasid era. Many questions need to be investigated in connection with the Abbasid court. What terminology was used in the sources to define the court and the courtiers? Who was a 'courtier'? What was the distinction between the household and the bureaucracy? How was the environment around the ruler organized spatially? Who filled it? How did it represent itself, and with what degree of ceremonial or spectacle? What were the rights and duties, obligations and privileges of the officers within the court and household? What do the sources tell us about the members of the caliphal households, whether women or princes?

In recent years, historians of the court have become interested in the ritual and symbolic aspects of rulership as part of the political system. They have, additionally, refocused attention on the whole personal and domestic world within which the ruler lived. ${ }^{1}$ This paper explores one aspect of the personal world that constituted the fourth/ tenth century caliphal court by focusing on the life and career of the Abbasid prince Abu al-'Abbas, eldest son of the caliph al-Muqtadir (AH 295-320/CE 908-932). Questions that I discuss revolve around the various spaces in which the prince lived, the education and tutorship that he received, the duties to which he was assigned from an early age, and the ceremonial role that he assumed. Information about his life prior to his assumption of the caliphate help us formulate a conception of the expected roles of princes at the fourth/tenth century Abbasid court, the possibilities and limitations open to them, and the networks that formed around them.

I have elsewhere investigated the varieties of functions that the eunuchs and harem stewardesses performed in the early fourth/tenth century Abbasid court. These investigations, like the one reported

\footnotetext{
1 Trevor Dean, 'The Courts', Journal of Modern History 67 (1995) pp. 136-151.
} 
here, are based on the premise that it is essential to limit the inquiry to a particular historical moment in order to free ourselves from the 'deadly sameness' of abstraction which allows no differences among times and places. ${ }^{2}$ The narratives pertaining to the reign of the Abbasid caliph al-Muqtadir offer particularly rich grounds for such an investigation. Accounts of this period underscore the weakening of the institutional integrity of the Abbasid caliphate which in turn contributed to problems plaguing the caliphate in the first part of the fourth/ tenth century. In this view, the youth and personal incapacity of alMuqtadir, in contrast to the vigour and ability of his immediate predecessors, opened the door to the 'meddling' of harem women and influential 'courtiers'. The sources for the reign of al-Muqtadir are, in some ways, unique in providing insights on the workings of the 'court' and the domestic world. For this particular period we are able to get behind the scenes and have a glimpse at the personal and informal networks operating at court.

\section{The Abbasid Courtier: Some Definitions}

The Abbasid court of the fourth/tenth century was polycentric and eclectic and seems to have constituted a space open to a vast range of outside influences. Sourdel defines the Abbasid elite as 'all those who surrounded the caliph, who had access to him, who were part of the court or the administration, and who served as his delegates in the army and the judiciary.' There was, thus, no real 'nobility' but rather those 'whose functions rather than their birth' provided them with the privilege of attending the caliph's audiences, of participating in the mazalim court and of figuring among those who gave the oath of allegiance to the new ruler. ${ }^{3}$

The term that most closely describes the courtiers is al-hashiya/alhawashi. In Tajarib al-umam, the most notable source for this period, Miskawayh (d. 421/1030) mentions that 'Ali b. 'Isa abolished increases which had been extended to all ranks of the army, to the eunuchs (al-khadam), to al-hashiya, and to all clerks (al-kuttab) and employees

\footnotetext{
2 Adrienne Rich, 'Notes Towards a Politics of Location', in: Feminist Postcolonial Theory: A Reader, Reina Lewis and Sara Mills, eds. (Edinburgh 2003) pp. 29-42.

${ }^{3}$ Dominique Sourdel, l'État imperial des caliphes abbasides: VIII ${ }^{e}-X^{e}$ siècle (Paris 1999) pp. 212-213.
} 
(al-mutasarrifin). In one passage Miskawayh states that the vizier Ibn al-Furat proceeded to examine 'Ali b. 'Isa with reference to the allowances of the hashiya: 'You, he said, in the five years of your administration, reduced the allowances of the harim (the court of women), the princes, al-hasham and the horsemen. In his defence, 'Ali b. 'Isa answered: 'Your plan for meeting expenditure was to transfer sums from the private to the public treasury, thereby pleasing the hashiya...' From this passage it would seem that the term al-hashiya is inclusive of the harim, the princes, the hasham and the horsemen. ${ }^{4}$

Miskawayh also provides another list where he states that during his second vizierate, 'Ali b. 'Isa adopted strict measures. He reduced the allowance of the eunuchs (al-khadam), the courts attendants (alhasham), the courtiers (al-julasa'), the table-companions (al-nudama'), the minstrels (al-mughannin), the purveyors (al-tujjar), the intercessors (ashab al-shafa'at) and those of the retainers (ghilman) and the dependents of the heads of bureaux (asbab ashab al-dawawin). ${ }^{5}$ Evidently large categories of people were implicated, making it quite difficult to determine the boundaries between the different categories of courtiers, retinue and bureaucrats. ${ }^{6}$

Another term which defines at least one circle of courtiers is the khassa/khawass. The khawass of al-Muqtadir are singled out among those who refused to partake in the conspiracy of Ibn al-Mu'tazz. Miskawayh states: 'There were present the commanders of the army, the heads of bureaux...the judges and notables (wujuh al-nas), with the exception of Abu al-Hasan b. al-Furat and the khawass of alMuqtadir." One way of defining the term is by exclusion: The term would thus exclude the groups that appear on this list. That the two terms khawass and hawashi define different categories of people seems clear in al-Sabi's text where it is stated that al-khawass and al-hawashi paid official visits to the vizier. ${ }^{8}$ But are these really two categories of people, clearly distinct, particularly in the minds of our authors? In his

${ }^{4}$ Ahmad b. Muhammad Miskawayh, Tajarib al-umam, Henry F. Amedroz, ed. (Oxford 1920) vol. 1, p. 108; Henry F. Amedroz and David S. Margoliouth, trans., The Eclipse of the Abbasid Caliphate (Oxford 1921) vol. 1, pp. 120-121.

${ }^{5}$ Miskawayh, Tajarib, vol. 1, p. 152; Amedroz and Margoliouth, Eclipse, vol. 1, pp. $170-171$.

${ }^{6}$ David Bruce Jay Marmer, The Political Culture of the Abbasid Court, 279-324

(A. H.), unpub. PhD. Diss., Princeton University (Princeton 1994) p. 183.

${ }^{7}$ Miskawayh, Tajarib, vol. 1, p. 5.

${ }^{8}$ Hilal al-Sabi', Kitab tuhfat al-umara' fi tarikh al-wuzara' (Beirut 1904) p. 268. 
discussion of the literary genre of the mirror of princes, al-'Allam lists the following seemingly synonymous terms referring to the courtiers: hashiya, khassa, bitana, a'wan, atba', khassat-al-khassa. ${ }^{9}$ There is a lack of clarity as to what these terms exactly mean in the various contexts in which they appear. The ways in which these terms were used in the texts and the ways in which they have been translated mask a confusion and an imprecise conceptual understanding of the terms and of the categories implied. It is, thus, necessary to undertake an exhaustive study of Abbasid terminology that would rely on concordances.

The other way, which is the one I have been pursuing, is to follow the life of particular individuals associated with the court. I have previously investigated the lives and careers of the caliph's mother, of the harem stewardesses Umm Musa and Zaydan, of the eunuch Muflih, and of the chamberlain Nasr. Tracing the roles of one of the princes helps fill the gap in our understanding of the roles of court and household during the caliphate of al-Muqtadir.

\section{The Birth of a Prince}

Archaeologically, the palaces related to the Abbasid dynasty in Baghdad are not well known since almost nothing of the monuments and of the urban fabric of the Abbasid city remains. However, some information about the Baghdad palaces can be derived from literary descriptions. ${ }^{10}$ We know that starting with the reign of al-Mu'tamid (256-279/870-892), the Hasani palace, built during the reign of Harun al-Rashid (170-193/786-809), became the center of a huge mass of buildings which were to form the core of Dar al-Khilafa. Al-Mu'tadid (279-289/892-902) built two palaces called al-Thurayya and al-Firdaws and laid foundations of a third, Qasr al-Taj. All three buildings stood on the Tigris bank, with great gardens stretching to the back, enclosing many minor palaces within their precincts.

By the time of al-Muqtadir, the caliphal residence had expanded into a vast complex of palaces, public reception and banqueting halls, residential quarters, prayer halls and mosques, baths, pavilions, sports grounds, pleasure and vegetable gardens, orchards and the like. It

9 'Izz al-Din al-'Allam, al-Sulta wa al-siyasa fi al-adab al-sultani (n. p. 1991) pp. 95-99.

${ }^{10}$ Oleg Grabar, The Formation of Islamic Art (New Haven 1987) p. 134. 
occupied an area nearly a square mile in extent, surrounded by a wall with many gates. ${ }^{11}$ The caliphal residence came to resemble a small city, deep within which the caliph and his throne room were located, reached by a long route. Al-Muqtadir enlarged al-Taj which became the principal caliphal residence and which was linked by a subterranean passage to the palace of al-Thurayya for the benefit of the harem women. ${ }^{12}$ The expansion of the palace complex allowed for the spatial articulation of political hierarchy.

Al-Muqtadir and his family lived in this great complex surrounded by his court and his guards, removed from the population and any agitation. Entry was reserved for a select group of individuals; that the rest could only imagine the opulence within the palace walls added to the mystery enshrouding the palace and increased the perception of distance separating the caliph from his people. ${ }^{13}$

The Dar al-Khilafa functioned simultaneously as a stage set for the representation of caliphal power, as the administrative centre of a vast empire and as a residence for the caliphal family. Prominent women had their own apartments within this complex and it is probably from this time that a separate women's quarter within the palace first emerged. ${ }^{14}$ The family members in the Abbasid harem of the early fourth/tenth century included the caliph's mother, the wives of the caliph, his concubines, the children and the unmarried, widowed or divorced sisters and aunts. The harem also included the administrative officers of the harem, and the female servants who performed the housekeeping tasks of the harem, and female slaves. Concerning the harem of al-Muqtadir, al-Sabi' states that: 'It is believed that in the days of al-Muqtadir...the residence contained 11,000 servants ...4,000 free and slave girls and thousands of chamber servants. ${ }^{15}$

The polygamous nature of the fourth/tenth-century caliphal harem was real. The notion of polygamy is not limited to the four legal wives but to the multiplicity of concubines who populated the caliphal harem. The concubine, once she had borne a child, became an umm walad and enjoyed a legally and socially enhanced position. The hope

${ }^{11}$ Guy Le Strange, Baghdad during the Abbasid Caliphate (Oxford 1900) p. 263.

${ }_{12}$ Le Strange, Baghdad, pp. 252-255; Yaqut, Mújam al-buldan (Beirut 1956) vol. 2, p. 4.

${ }^{13}$ D. Fairchild Ruggles, Gardens, Landscape, and Vision in the Palaces of Islamic Spain (University Park, Pa. 2000) p. 92.

${ }^{14}$ Hugh Kennedy, The Court of the Caliphs (London 2004) p. 164.

${ }^{15}$ Hilal al-Sabi', Rusum dar al-Khilafa, Mikha'il 'Awwad, ed. (Baghdad 1964) p. 8. 
of attaining the status of queen mother must have been entertained by every concubine taken into the harem. The prospect was not impossible since al-Muqtadir's mother herself had climbed through these ranks: A Byzantine by birth, she was bought by the caliph al-Mu'tadid; after giving birth to her son, Ja'far, she achieved the status of umm walad and was freed on al-Mu'tadid's death.

One concubine in the harem of al-Muqtadir was Zalum. On Tuesday night, the fifth of Rabic II, the year 296/908, Zalum brought forth to the world Abu al-'Abbas Muhammad, the eldest son of al-Muqtadir. ${ }^{16}$ Zalum is not mentioned on this occasion. It is only later on, once her son became caliph, that Zalum is mentioned in the sources. ${ }^{17} \mathrm{Her}$ bringing forth a male child meant that she would be freed as $u m m$ walad on al-Muqtadir's death. Upon the accession of her son to the caliphate, she would become an influential person at the court.

'Arib mentions that Abu al-'Abbas was born in Dar Hanina', just before dawn. ${ }^{18}$ The royal children lived with their mothers in the harem of the caliphal palace. In 302/914, at five years of age, Abu al-'Abbas and four of his brothers were circumcised and honoured with a lavish celebration. ${ }^{19}$ Al-Suli also provides a vignette which shows all the royal children gathered around their father, al-Muqtadir. The youngest son at the time was al-Fadl. The caliph made him sit with him on his throne and cuddled him. The caliph thought that his action may have displeased his eldest son Abu al-'Abbas, and so he addressed him reminding him that al-Fadl was the youngest: 'It still holds true that tenderness and playfulness are the share of the youngest, while respect and due position are the share of the eldest. ${ }^{20}$

One source provides a description of Abu al-'Abbas at a later age, once he had become Caliph al-Radi: He was short and slender, browneyed, high-colored and smooth-cheeked. ${ }^{21}$ One description pertaining

16 Abu Bakr al-Suli, Ma lam yunshar min awraq al-Suli: akhbar al-sanawat 295-315, Hilal Naji, ed. (Beirut 2000) p. 68. See also al-Mas'udi, Muruj al-dhahab wa ma'adin al-jawhar, Charles Pellat, ed. (Beirut 1974) vol. 5, p. 217. Ibn al-Sa'i in Nisa' al-khulafa' (Cairo, n.d.) pp. 106-108, includes some information on one of the concubines of al-Muqtadir: Khumra who was an umm walad.

${ }^{17}$ Abu Bakr al-Suli, Akhbar al-Radi billah wa al-Muttaqi lillah, J. Heyworth Dunne, ed. (Cairo 1935) p. 1.

18 'Arib, Silat al-Tabari, Michael Jan De Goeje, ed. (Leiden 1897) p. 33.

19 Al-Hamadhani, Takmilat tarikh al-Tabari, Albert Kan'an, ed. (Beirut 1959) p. 22.

20 Al-Suli, Ma lam yunshar, p. 32.

${ }^{21}$ Al-Mas'udi, Kitab al-tanbih wa al-ishraf, Michael Jan De Goeje, ed. (Leiden 1993) p. 388. 
to his character as an adult mentions his noble manners, his judicious usage of the literary arts, as well as his active participation in the discussions of the learned and the 'philosophers. ${ }^{22}$

\section{The Education of a Prince}

Abu al-'Abbas was put into the palace school at an early age, in 302/914. ${ }^{23}$ His first tutor was al-'Arudi who was appointed by al-Muqtadir to educate the young prince. ${ }^{24}$ When Abu al-'Abbas was in the prime of his youth al-'Arudi recalls mentioning to the prince a report on the subject of greatness and the attributes of those in leadership, what is to be commanded and what is to be reprimanded. As he spoke, the prince took down notes in his own handwriting. Later on al-'Arudi saw him intently studying what he had written and trying to apply it in his actions. Abu al-'Abbas told his teacher: 'God willing I should achieve these qualities so as to become a paragon of these virtues. ${ }^{25}$

Abu al-'Abbas's most famous tutor was al-Suli (d. 336/946), who wrote a history of the contemporary caliphs based on first-hand knowledge. He was a prominent man of letters in Baghdad, a tutor and companion of several Abbasid caliphs. Evidence of al-Suli's tutorship of Abu al-'Abbas is related in a number of anecdotes. Al-Suli recounts that the chamberlain Nasr prescribed that 'I place myself at the disposition of the two princes, Abu al-'Abbas and Harun.' Al-Suli was assigned to meet with them twice a week. He found the two princes to be intelligent and sensible, albeit lacking in knowledge. ${ }^{26}$

Al-Suli underlines that Abu al-'Abbas was the more refined and more avid learner of the two. He bought for them books of jurisprudence, poetry, language and history. The princes organized their respective libraries and they studied, under the direction of al-Suli, history and poetry. However, al-Suli told them that prophetic tradition, hadith, was more profitable for them than anything else. For that purpose he

\footnotetext{
Al-Mas'udi, Muruj, vol. 5, p. 218.

Al-Hamadhani, Takmila, p. 22.

Al-Suli, Akhbar, pp. 8-9.

Al-Mas'udi, Muruj, vol. 5, p. 222.

Al-Suli, Akhbar, p. 25.
} 
brought into the court the most important traditionist of that time, Abu al-Qasim b. bint Manic. ${ }^{27}$

Al-Suli was appointed to be the tutor of Abu al-'Abbas in 307/91920 and continued in this function until 315/927. During this period he had to struggle with the interferences of the caliph's mother who had her agenda regarding the education of her grandson. Al-Suli recalls a day when Abu al-'Abbas was reading the poetry of Bashar b. Burd and had in front of him books of philology and history when the eunuchs of his grandmother arrived. They took away the books and Abu al-'Abbas was upset with their action. Al-Suli tried to calm him down by saying that his grandmother had been informed that he was reading 'proscribed' books. A few hours later the eunuchs brought the books back. The prince Abu al-'Abbas told them:

Tell whoever ordered you to do what you have done that these are purely learned and useful books on theology, jurisprudence, philology, poetry, history... and are not the kinds of books that you read, such as stories of the marvels of the sea, Sindbad, and the fable of the cat and the mouse..$^{28}$

Al-Suli also taught the princes a number of philological treatises, including the work entitled khalq al-insan, by al-Asma $i$ (d. 213/828). Eunuchs reported to al-Muqtadir and his mother that al-Suli was teaching the princes the names of the genital organs. Chamberlain Nasr once more intervened, interviewed al-Suli, asked him to bring in the volume and then took it to the caliph to explain to him that such knowledge is necessary for jurists and judges. ${ }^{29}$

That the caliph's mother and her entourage had a different view regarding the education of the princes is clearly stated in an anecdote in which the prince Abu al-Abbas is praised by the scholar Husayn al-Mahamili for his knowledge acquired through al-Suli's teaching. Al-Mahamili asked that his praise be reported to the harem stewardess Zaydan: 'What have you done for the man [al-Suli] who has transformed the prince in such a way?' The answer that was given by Zaydan reflected that their ideas were diametrically opposed to those of al-Suli:

${ }^{27}$ Al-Suli, Akhbar, p. 25. The mother of the princes declined to pay the traditionist. It was the chamberlain Nasr who immediately agreed to pay his fees.

${ }_{28}$ Al-Suli, Akhbar, pp. 5-6.

29 Al-Suli, Akhbar, pp. 25-26. 
The qualities of this man [al-Suli] are in the eyes of al-Sayyida [alMuqtadir's mother] and those who serve her, shortcomings. So please tell him: we do not want our children to be men of letters or learned scholars... Look at their father [caliph al-Muqtadir]: we find in him all the qualities that we like and yet he is not a learned man. ${ }^{30}$

It was soon after that al-Suli left the service of Abu al-'Abbas, although he maintained a correspondence with his pupil. ${ }^{31}$ The bonds between the prince and his tutor remained so strong that later on, when Abu al-'Abbas became caliph, he asked al-Suli to help him choose a throne name. ${ }^{32} \mathrm{Al}$-Suli became one of his favoured boon-companions.

At some point in their education, the princes seem to have been assigned to different individuals at court for further training. The tutorship of the princes seems to have constituted one of the spaces of competition of the factions at court. Al-Suli states that Abu al-'Abbas was put under the tutorship of Mu'nis, the commander of the troops (kana fi hijr Mu'nis). ${ }^{33}$ His brother Harun was entrusted to Nasr the chamberlain for training; the third brother 'Abbas grew up under the tutorship of Gharib, the maternal uncle of al-Muqtadir. ${ }^{34}$ The three princes were thus attached to the most important figures at court.

We do not know what kind of tutorship Abu al-'Abbas received from Mu'nis but the loyalty that they felt towards each other was obvious during their difficult years. Upon the death of al-Muqtadir, Mu'nis came out clearly in favour of the succession of Abu al-'Abbas. Miskawayh states that upon the death of al-Muqtadir Mu'nis burst into tears saying:

You have killed him! By God we shall all be killed. The least that you can do is to announce that this happened without your intention or order and to place on the throne his son Abu al-'Abbas, for he is my nursling (tarbiyati); once he becomes caliph, his grandmother... his brothers and his father's retainers will be willing to spend money. ${ }^{35}$

${ }^{30}$ Al-Suli, Akhbar, p. 26.

31 Al-Suli, Akhbar, pp. 27-28.

32 Al-Suli, Akhbar, pp. 2-4.

${ }_{33}$ Al-Suli, Akhbar, p. 5; According to 'Arib, the prince Harun had first as a tutor Nasr the chamberlain and following the death of the latter, Yaqut the chamberlain was appointed as Harun's tutor. In 'Arib, Silat, pp. 154-155.

${ }^{34}$ Al-Suli, Akhbar, p. 5.

${ }_{35}$ Miskawayh, Tajarib, vol. 1, pp. 241-242; Trans. in Amedroz and Margoliouth, Eclipse, vol. 1, p. 272. 
However, when it was observed that to promote this prince would in fact perpetuate the existing regime, Mu'nis yielded to the argument and al-Qahir succeeded.

\section{The Court of the Prince}

Unlike other court models, such as Versailles, for instance, which was self-contained, outside the city, subsuming both the prince's household and the administration, the court of al-Muqtadir was an integral part of the city, a factor manifested by the sheer amount of coming and going between the Dar al-Khilafa and the city of Baghdad. We know that the viziers lived outside the caliphal residence and that they went to court on the days of audience. The palace of Mu'nis was located in the Shammasiyya quarter while the office of the police chief was across the river from the palace complex. ${ }^{36}$ The residence of the Chamberlain Nasr was, by contrast, inside Dar al-Khilafa and this allowed him precious access to the caliph.

Abu al-'Abbas received a home of his own at an early age. In 306/918 the vizier Hamid b. al-'Abbas took up residence in Bab al-Basra, and the caliph gave the vacant waziral palace to prince Abu al- Abbas. ${ }^{37}$ When Ibn al-Furat was appointed vizier five years later, al-Muqtadir returned the waziral palace to him, at his request. There is no indication as to where Abu al-Abbas moved. ${ }^{38}$ Having a residence inside the palace complex would have afforded a useful physical proximity for the prince as he would have been able to influence caliphal decisions in a more immediate way. However, by establishing a residence outside the royal complex, the prince was able to assert his independent political identity. This increased the possibility of his participation in a coup against his father. ${ }^{39}$ Indeed, in 319/931, al-Muqtadir heard that Mu'nis was plotting to carry off the prince Abu al-'Abbas from his palace in al-Mukharrim to Egypt or Syria and there proclaim him caliph. Al-Muqtadir therefore returned the prince from al-Mukharrim

36 Al-Sabi', Rusum, p. 31.

37 Al-Hamadhani, Takmila, p. 30.

38 Al-Hamadhani, Takmila, p. 43.

39 Marmer, Political Culture of the Abbasid Court, p. 137. 
palace to his apartment in the caliphal palace to keep a closer watch over him. ${ }^{40}$

Abu al-'Abbas gradually developed his own sub-court. He acquired very early on a personal retinue. When in 301/913 the commander Mu'nis al-Khazin died, his men were joined to the detachment of Abu al-'Abbas. ${ }^{41}$ We also know that Abu al-'Abbas had a secretary, katib, Abu Sa id b. 'Amru, who was in fact his closest servant (akhass al-nas bihi). ${ }^{42} \mathrm{~A}$ eunuch in the service of Abu al-'Abbas is also mentioned: he was sent by the prince to announce to al-Suli that al-Khasibi had been appointed vizier in 313/925. ${ }^{43}$

The prince also had his own majlis. The majlis/majalis as a versatile social and cultural institution could house activities 'ranging from serious religious, exegetical, philosophical and intellectual debate to frivolous or amusing poetic recitation and composition, singing, winedrinking and an ostentatious enjoyment of leisure in the company of witty and elegant people. ${ }^{34}$ The boon-companions (nadim/nudama') formed a narrow circle of companions who were expected to converse about all sorts of subjects and to participate in many types of activities. ${ }^{45}$ Von Grunebaum has specified that "what secured success in social gatherings of this kind would be first and foremost esprit. An epigrammatic turn of mind would... go far in making a visitor to the majlis an effective contributor. ${ }^{36}$ The nadim was also expected to function as a source of council and moral guidance. ${ }^{47}$ The very principle of the majlis allowed the meeting of two axes of organization and sociability: a horizontal egalitarian axis, that of fraternity; and a vertical hierarchical axis, that of 'distinction'. This intimate court was not an extension of the circle of servants. The criteria for recruitment emanated directly from the personal choice of the host. ${ }^{48}$

${ }^{40}$ Miskawayh, Tajarib, vol. 1, p. 221; al-Hamadhani, Takmila, p. 83.

${ }^{41}$ Al-Suli, Ma lam yunshar, p. 94; 'Arib, Silat, p. 45.

42 Al-Suli, Akhbar, p. 5.

43 Al-Suli, Ma lam yunshar, p. 149.

44 Cynthia Robinson, In Praise of Song: The Making of Courtly Culture in al-Andalus and Provence, 1005-1134 A.D. (Leiden 2002) p. 75.

45 Anwar Chejne, 'The Boon-Companion in Early 'Abbasid Times', Journal of the American Oriental Society 85 (1965) pp. 327-335.

${ }^{46}$ G.E. Von Grunebaum, 'Aspects of Arabic Urban Literature mostly in the Ninth and Tenth Centuries', Islamic Studies 8 (1969) pp. 281-300.

${ }^{47}$ Julie Scott Meisami, Medieval Persian Court Poetry (Princeton 1987) p. 7.

48 See Bernard Hours, Louis XV et sa cour: le roi, l'étiquette et le courtesan. Essai historique (Paris 2002) pp. 117-123. 
We have several reports on Abu al-'Abbas's hosting of such gatherings. On one occasion Abu al-'Abbas invited his brother Harun to drink with him in the palace of al-Thurayya. The occasion resulted in an exchange of verses during which Abu al-'Abbas recited poems by Abu Nuwas. ${ }^{49}$ Al-Suli mentions another instance when Abu al-'Abbas invited him to participate in an evening of drinking in his palace in alMukharrim. ${ }^{50}$ We also read of a majlis hosted by the caliph al-Muqtadir to which were invited Abu al-'Abbas and his brothers: 'We went in our boon-companionship attire, except for my brother Harun,' who was then ordered by the caliph to put on the proper attire. ${ }^{51}$ Al-Suli has described Abu al-'Abbas on such occasions: he was intelligent, prompt at understanding whatever was said, and quick to find his words without needing to think. ${ }^{52}$

The composition of such gatherings is provided by al-Suli, who gives an eyewitness description of the first gathering of the Tablecompanions of Abu al-'Abbas, after he became caliph. The caliph sent to al-Suli a message in which he inquired about the companions of earlier caliphs who were still around and who were still fit to be invited to his receptions. Al-Suli answered that of such companions, the only remaining one was Ishaq $\mathrm{b}$. al-Mu'tamid but he suggested others who have the qualities necessary to be present at the caliph's receptions. When the group arrived at the caliphal palace for the caliph's reception, they sat in strict order: to the right sat first the prince Ishaq $b$. al-Mu'tamid; then al-Suli, then a philologist, private tutor of a Prince, and Ibn Hamdun. To the left sat three literary courtiers of the family of Munajjim and Baridis of high official descent. ${ }^{53} \mathrm{Al}$-Suli reports on the two activities that dominated such receptions: reciting poetry and drinking wine. ${ }^{54}$

In order to maintain a separate household and pay social companions and military units, the prince needed income. The stipends allotted to the princes were a most sensitive financial issue at court. Aspirants to the wazirate offered increases of stipends. In 304/916,

${ }^{49}$ Al-Suli, Akhbar, p. 8.

50 Al-Suli, Akhbar, p. 50.

${ }^{51}$ Al-Suli, Ma lam yunshar, p. 31.

52 Al-Suli, Akhbar, p. 7.

53 Al-Suli, Akhbar, pp. 8-9. See this passage also in Adam Mez, The Renaissance of Islam, Salahuddin Khuda Bukhsh and David S. Margoliouth, trans. (London 1937) pp. 143.

54 Al-Suli, Akhbar al-Radi, pp. 9, 19, 55. 
for instance, 'Ibn al-Furat undertook to pay al-Muqtadir, his mother and the two princes 1500 dinars a day of which one thousand dinars went to the caliph, 333 and one third to his mother, and 166 and two thirds to the two princes Abu al-'Abbas and Harun. ${ }^{55}$ We also have the budget statement prepared by 'Ali b. 'Isa for the year 306/918 and it includes the monthly allowance prescribed to Umm al-Muqtadir, to the princes, to the female relatives and to the servants. ${ }^{56}$

\section{The Roles of the Prince}

From an early age, Abu al-'Abbas received important governmental posts. In 301/913, while he was four years old, a robe of honour was bestowed on him. He was given command of the war in Egypt and the Maghrib. Mu'nis al-Khadim was appointed his deputy in Egypt. ${ }^{57}$ Abu al-'Abbas could not take on the governorship of the western provinces at this young age; he never took on such duties in practice. Indeed, much later on, in 318/930, al-Muqtadir robed and appointed Abu al-'Abbas to the West, and again Mu'nis was asked to perform the prince's duties, even though the prince was now over twenty years old. ${ }^{58}$ In fact with all of the military crises of the period we never hear of Abu al-'Abbas or any of the other princes involved in military actions. Although he received official appointments and although he developed a large retinue, the prince does not seem to have been involved in the real politics of his time. This was in line with what had effectively become the practice starting with the mid-third/ninth century when the caliph's children were confined to the palaces of Baghdad and Samarra' rather than being sent to govern the provinces. ${ }^{59}$

One main function that Abu al-'Abbas did fulfill was to act as an emissary of his father in sensitive missions. Al-Muqtadir used Abu al-'Abbas as an intermediary with important state officials, especially when he wanted to convey a personal message to someone's home. Abu al-'Abbas undertook such a delicate mission in 317/929. When Mu'nis had heard rumors that he would be replaced as chief

\footnotetext{
5 Miskawayh, Tajarib, vol. 1, p. 42.

6 Al-Sabi, Rusum, pp. 21-25.

7 Miskawayh, Tajarib, vol. 1, p. 32.

58 Miskawayh, Tajarib, vol. 1, p. 202.

59 Kennedy, Court of the Caliphs, p. 168.
} 
commander, al-Muqtadir sent Abu al-'Abbas and the vizier Ibn Muqla in order to alleviate Mu'nis's fears and suspicions and to convince him of the caliph's good intentions and continued favour. Perhaps al-Muqtadir employed Abu al-'Abbas in this instance because of the prince's special relationship with Mu'nis, but, in any case, since the caliph was restricted by protocol from leaving the palace and delivering the message in person, sending his son was the most effective way of getting around such barriers while maintaining a symbolic authority that enhanced that of the caliph.

Indeed, the main role that Prince Abu al-'Abbas seems to have been assigned was a ceremonial one. By the fourth/tenth century caliphs had almost completed the process of distancing themselves from the general populace, removing themselves architecturally and ceremonially. Gulru Necipoglu singles out one palatine paradigm which emerged during the third/ninth and fourth/tenth century and which was characterized by sprawling extra-urban palatine complexes no longer attached to congregational mosques. This change in the spatial relationship between the palace and the mosque marked the increasing seclusion of the Abbasid caliphs from their subjects. ${ }^{60}$ The ceremonies codified the internal structure of the court and also presented to the public an idealized image of the caliphate. Changing ideas about rulership were articulated in the idiom of protocol and ceremonial.

According to Paula Sanders, 'the protocol of the courts expressed symbolically a developing set of assumptions about authority, rule and rulers. ${ }^{61}$ During the reign of al-Muqtadir the weakness of the caliph and of the state were compensated for by ritualized and ceremonial forms. Cynthia Robinson has argued that the ceremonial space served as a place where dynastic solvency, legitimacy and power could be physically demonstrated. ${ }^{62}$ Malcom Vale has indicated that the semblance of power 'could be just as potent a force in the creation and sustenance of princely ideology. ${ }^{163}$ By the fourth/tenth century,

\footnotetext{
${ }^{60}$ Gülru Necipoğlu, 'An Outline of Shifting Paradigms in the Palatial Architecture of the Pre-Modern Islamic World', Ars Orientalis 23 (1993) pp. 3-24.

${ }^{61}$ Paula Sanders, Ritual, Politics and the City in Fatimid Cairo (Albany 1994) p. 15.

${ }^{62}$ Robinson, In Praise of Song, p. 49.

${ }^{63}$ Malcolm Vale, The Princely Court: Medieval Courts and Culture in North-West Europe, 1270-1380 (Oxford 2001) pp. 200-207.
} 
ceremonies became more sumptuous, the caliphs seeking to compensate for the loss of their powers by a greater magnificence. ${ }^{64}$

Our knowledge of daily ceremonial is slight. The invisible caliph was occasionally made officially visible to members of his court, although we do not have information on his routine daily visibility to his officials and courtiers. We have even less information about the ceremonial surrounding members of the caliphal household, notably the princes. Abu al-'Abbas appears in the sources most frequently in processions in which his primary function was to add royal dignity to the proceedings. There the prince was the center of an elaborate event. Surrounded by the most important men of state, the prince was the real focus of the procession. On those occasions, the procession is often described in detail, and even seems like the most important aspect of the entire event.

The young prince's first appointment over the Maghrib and Egypt was celebrated by an impressive parade:

Abu al-Abbas... rode from the Hasani palace while in front of him was the banner which al-Muqtadir had given him over the Maghbrib. Accompanying the prince were all of the commanders, the al-hujariyya retainers and many eunuchs, all surrounding his mount. On his right was 'Ali b. 'Isa; Mu'nis was on his left; and the chamberlain Nasr was in front of him. He traveled along the main road and returned via the river, with the people accompanying him... ${ }^{65}$

The procession included the most powerful men of state: the vizier, the chamberlain, and the chief commander. In 304/916 as part of the prisoner parade for the rebel al-Husayn b.Hamdan,

al-Husayn was conducted from the Shammasiya gate to the caliphal palace attached to a cross... His son was exposed on another camel. In front of them went the prince Abu al-'Abbas, the vizier 'Ali b. 'Isa, the commander Mu'nis... ${ }^{66}$

The prince's presence added weight to this important occasion which was celebrating the Abbasid state's victory over the rebel al-Husayn b. Hamdan. Abu al-'Abbas is also seen repeatedly escorting and receiving

${ }^{64}$ Dominique Sourdel, 'Robes of Honor in Abbasid Baghdad during the Eighth to the Eleventh Century', in: Robes and Honor: The Medieval World of Investiture, Stewart Gordon, ed. (New York 2001) pp. 137-145.

65 Al-Suli, Ma lam yunshar, p. 93; 'Arib, Silat, p. 43.

${ }^{66}$ Miskawayh, Tajarib, vol. 1, pp. 37-8; Al-Hamadhani, Takmila, p. 24; al-Suli, Ma lam yunshar, p. 104; 'Arib, Silat, p. 57. 
Mu'nis to and from military campaigns. For instance, when Mu'nis was heading with the troops towards Egypt in 308/920, Abu al-'Abbas accompanied him to his camp site. ${ }^{67}$ Upon Mu'nis' return to Baghdad the following year, he was received by Abu al-'Abbas. ${ }^{68}$ We also read that in 315/927, as Mu'nis was leading the troops to fight the Byzantines, he was escorted by Abu al-'Abbas, 'Ali b. 'Isa, Chamberlain Nasr, and Harun b. Gharib. ${ }^{69}$

Such public processions made Abu al-'Abbas the focus of important state rituals. As a symbolic representative of the caliph, Abu al-'Abbas disseminated the caliph's majesty to the public while the ruler remained distanced in the palace. The prince's presence during processions added dignity to any event and brought to the public of Baghdad a sense of caliphal splendour and decorum. Public perceptions of the caliph via the prince influenced the shaping of contemporary maps of political reality, informing, correctly or incorrectly, assessments of where power lay and the general well-being of the state. The effectiveness of the caliphate and court have at least as much to do with representations, beliefs, expectations and rumours, as with 'objective' arrangements. ${ }^{70}$ The glorification of the prince, moreover, served to reinforce two political principles that supported al-Muqtadir's claim to the caliphate: the notion of inheritance and primogeniture and that this particular branch of the Abbasid family should rule. Al-Muqtadir, thus, used Abu al-'Abbas to assert the political principle of succession. ${ }^{71}$

\section{The Plight of the Prince}

Upon his accession in 320/932, al-Qahir, brother of al-Muqtadir, ordered raids on the houses where the sons of al-Muqtadir were possibly hiding. This order was carried out until Abu al-'Abbas, Harun, 'Ali, al-'Abbas, Ibrahim, and al-Fadl were found. ${ }^{72}$ Abu al-'Abbas was placed

${ }^{67}$ Al-Suli, Ma lam yunshar, p. 125; 'Arib, Silat, p. 79.

${ }_{68}$ Al-Hamadhani, Takmila, p. 31.

${ }^{69}$ Al-Hamadhani, Takmila, pp. 65-6.

${ }^{70}$ Jacques Revel, 'The Court', in: Realms of Memory, Vol. II: Traditions, Pierre Nora, ed., Arthur Goldhammer, trans. (New York 1997) pp. 72-122.

${ }_{71}$ Marmer, Political Culture, pp. 148-9.

72 Ibn al-Athir, al-Kamil fi al-Tarikh, Carl Johan Tornberg, ed. (Beirut 1979) vol. 8, p. 246; al-Suli, Akhbar, p. 1 . 
under house arrest for years. After he became caliph, Abu al-'Abbas, recounted during a majlis, what he had had to endure at the hands of al-Qahir: Abu al-'Abbas and his mother languished in confinement; the prince was afraid night and day of being put to death, and he had to disguise his feelings towards al-Qahir who could not be trusted. ${ }^{73}$ On another occasion al-Radi told al-Suli that after the execution of Mu'nis, al-Qahir sent him Mu'nis' head as a threat:

At the time I was imprisoned because I had been under the tutorship of Mu'nis. I understood his intention and decided to misguide him as to my true feelings. And so I prostrated myself thanking God and manifested in front of the eunuchs a great happiness...I started thanking al-Qahir... and wrote him verses. ${ }^{74}$

For a number of years Abu al-'Abbas experienced a difficult and sometimes dangerous isolation. His accession to the caliphate came as a surprise to him. Indeed, he states that he did not seek power and did not strive to attain it:

I got into power without having attempted anything to obtain it and without having desired it...not out of ignorance on my part as to what it entails in honour and majesty but because of the changed circumstances, the paucity of money, the army's insatiability, and the country's ruin. It seemed to me that I would have as companions, distress, sadness, anger, preoccupations, more than the expected happiness and joy... But I hope that God will help me because of my good intentions...75

His good intentions paid off, at least verbally, in the sources. The judgment on his character is mostly positive. Miskawayh talks about him as

a scholar and poet, with a command of elegant language; a man who loved the society of the learned, and was never without companions; a man of liberal mind and generous disposition. ${ }^{76}$

Abu al-'Abbas died of illness in 329/940. According to later historians, the death of al-Radi brought changes to the caliphate: he was the last caliph to leave a compiled collection of poetry; the last caliph to pronounce regularly in public the Friday sermon; the last to entertain boon-companions; and the last whose establishment was on the scale

Al-Suli, Akhbar, p. 17.

Al-Suli, Akhbar, pp. 49-50.

5 Al-Suli, Akhbar, pp. 16-17.

${ }_{76}$ Miskawayh, Tajarib, vol. 1, p. 417. Trans. in Amedroz and Margoliouth, Eclipse, vol. 1, p. 462 . 
adopted by his forefathers. ${ }^{77}$ Following Abu al-'Abbas' death, Bajkam stated that the caliph 'was intelligent, crafty and, a flatterer...but I blame him for having been too weak and for having let his passions influence his judgment. ${ }^{78}$ His tutor and companion al-Suli praised him in the following terms:

Among the Abbasids caliphs, he was the most talented poet, the most fecund in poetry, the most generous and kind to his companions. I have never seen or heard of a caliph better than him in nobility of character, more liberal in money or in food, to the point of exaggeration, or in his gifts of cloths and perfumes. He had not the slightest avarice... had he not followed his passions in the ways he did...I would think that he has no superior. ${ }^{79}$

${ }^{77}$ Ibn al-Athir, al-Kamil fi al-tarikh, vol. 8, p. 368.

${ }_{78}$ Al-Suli, Akhbar, p. 43.

79 Al-Suli, Akhbar, p. 19. See also al-Mas'udi, Muruj, vol. 5, p. 228. 